(C) 1987 Martinus Nijhoff Publishers, Dordrecht. Printed in the Netherlands.

\title{
Weed control using allelopathic sunflowers and herbicide
}

\author{
GERALD R. LEATHER
}

Foreign Disease-Weed Science Research, USDA-ARS, Bldg. 1301, Fort Detrick, Frederick, MD 21701, USA

Received 26 March 1986. Revised September 1986.

Key words Allelopathy Autotoxicity Sunflower yield Weed biomass

Summary Field studies were conducted to determine if season long weed control could be achieved by combining the use of an herbicide with the natural allelochemicals produced by cultivated sunflower (Helianthus annuus L.). The weed biomass was reduced equally in plots planted with sunflowers, whether or not the herbicide was applied in each of 4 years. Weed control diminished the second year in all plots that received the same treatments as had been applied the previous year. This diminished efficacy was attributed to reduced emergence of sunflower (13.5 to 45.2 percent) in second-year plots, as a result of autotoxicity from sunflower crop residues remaining after the first-year harvest.

\section{Introduction}

Allelopathy and its role in agroecosystems has been evaluated with respect to effects of crop residues in succeeding crops ${ }^{5,8}$, weed residues on crop yield $^{3}$, and crop plants on weeds ${ }^{14,18}$. Others ${ }^{1,8,17}$ have reviewed the research on allelopathy and its implications in agriculture, especially as it relates to weed control.

Sunflowers (Helianthus spp) are allelopathic in nature and exhibit autotoxicity. $H$. scaberrimus Ell. ( $=H$. rigidus Desf.) was observed to form a 'fairy ring' in Minnesota, USA populations of this plant ${ }^{6}$. Other species of sunflower influence succeeding generations similarly through the decomposition and release of allelochemicals from underground plant parts ${ }^{7}$. H. annuus L., the source of germplasm for confection and oilseed sunflowers, is allelopathic to invading weeds in old fields ${ }^{20}$, and reduces crop yields as a weedy component of agroecosystems ${ }^{2,11,15}$.

Aqueous leaf extracts of cultivated sunflower alter the water balance and inhibit the growth of grain sorghum (Sorghum bicolor Moench.) ${ }^{19}$, and are allelopathic to many weeds ${ }^{13}$. The responsible allelochemicals are present in root, stem, and leaf tissue ${ }^{13}$, and seed hulls ${ }^{16}$. The expression of allelopathic effects by sunflower is subject to environmental modification, including the nutrient status of the plant ${ }^{10,12}$.

Based on demonstrated weed inhibition by sunflower in field plots ${ }^{13}$, this research was conducted to determine if season-long weed control could be achieved by exploiting the use of an herbicide for control early in the season and the allelopathic effects of cultivated sunflowers for late season control. 
Table 1. Biomass $\left(\mathrm{g} / \mathrm{m}^{2}\right)^{*}$ of weeds in first-year sunflower plots treated with EPTC

\begin{tabular}{|c|c|c|c|c|}
\hline \multirow[t]{2}{*}{ Herbicide rate $(\mathrm{kg} / \mathrm{ha})$} & \multicolumn{4}{|l|}{ Year } \\
\hline & 1982 & 1983 & 1984 & 1985 \\
\hline 0.00 (sunflowers) & $47.8 \mathrm{a}$ & $56.0 \mathrm{a}$ & $122.0 \mathrm{a}$ & $7.6 \mathrm{ab}$ \\
\hline 0.84 (sunflowers) & 123.5ab & $40.0 \mathrm{a}$ & $59.9 \mathrm{a}$ & $12.5 \mathrm{ab}$ \\
\hline 1.68 (sunflowers) & $82.5 \mathrm{ab}$ & $217.4 a b$ & $179.2 \mathrm{ab}$ & $0.5 \mathrm{a}$ \\
\hline 2.25 (sunflowers) & $46.2 \mathrm{a}$ & $40.0 \mathrm{a}$ & $64.4 \mathrm{a}$ & $1.4 \mathrm{a}$ \\
\hline 3.36 (sunflowers) & $64.2 \mathrm{a}$ & $46.8 \mathrm{a}$ & $90.7 \mathrm{a}$ & $0.4 \mathrm{a}$ \\
\hline 3.36 (no sunflowers) & -** & $62.9 \mathrm{a}$ & $135.3 \mathrm{a}$ & $2.0 \mathrm{a}$ \\
\hline 0.00 (no sunflowers) & $148.9 \mathrm{~b}$ & $263.5 b$ & $349.5 b$ & $19.1 b$ \\
\hline
\end{tabular}

* Means within columns having the same letter are not significantly different at $P=0.10$ as analyzed by Duncan's Multiple Range Test.

** Treatment not included in 1982.

\section{Materials and methods}

Field experiments were conducted on Duffield silt loam (ultic hapludolfs, fine-loamy, mixed mesic) soil from 1982 to 1985 within a 2-ha area. EPTC (S-ethyl dipropyl carbamothioate) herbicide was applied in $280 \mathrm{l} /$ ha water preplant-incorporated 1 day prior to seeding sunflowers (hybrid 8941) in $45 \mathrm{~cm}$ rows at a density of $12 / \mathrm{m}^{2}$ with a planet-Jr seeder. Plots were fertilized and limed according to recommendations based on results of soil tests made in November of the previous year. In each of the 4 years, new plots were established (first-year) and also, treatments were applied to plots from the previous year (second-year).

\section{First-year plots}

The soil was plowed to a depth of $20 \mathrm{~cm}$ in the fall for newly established plots and the seed bed prepared the following May. The experimental design was a randomized complete block with 7 treatments in 4 blocks. Each plot was $5 \mathrm{~m}$ by $5 \mathrm{~m}$. The treatments were: sunflowers with herbicide applied at $0.0,0.84,1.68,2.25,3.36 \mathrm{~kg} / \mathrm{ha}$, open plots (no sunflowers), and open plots with herbicide at $3.36 \mathrm{~kg} / \mathrm{ha}$. The number of sunflower plants emerged was determined 3 weeks after planting. Weed density was calculated by the method of Goldsmith and Harrison ${ }^{9}$ using stem counts from four $-0.1 \mathrm{~m}$ quadrats on a transect at mid-plot 6 weeks after treatment. Biomass of weeds was obtained by cutting all weeds from $0.025 \mathrm{~m}^{2}$ within each quadrat, and drying in an oven at $60 \mathrm{C}$ for $48 \mathrm{~h}$. At petal drop, sunflower heads were harvested to prevent predation by birds. Fresh weight of the heads was determined in the field at time of harvest. After harvest, plots were cultivated with a disc harrow in two directions to incorporate sunflower and weed residues.

Table 2. Biomass $\left(\mathrm{g} / \mathrm{m}^{2}\right)^{*}$ of weeds in second-year sunflower plots treated at varying rates of EPTC

\begin{tabular}{|c|c|c|c|}
\hline \multirow[t]{2}{*}{ Herbicide rate $(\mathrm{kg} / \mathrm{ha})$} & \multicolumn{3}{|l|}{ Year } \\
\hline & 1983 & 1984 & 1985 \\
\hline 0.00 (sunfiowers) & $231.3 b c$ & $286.8 \mathrm{ab}$ & $31.1 \mathrm{a}$ \\
\hline 0.84 (sunflowers) & $125.6 \mathrm{ab}$ & $241.6 \mathrm{a}$ & $62.3 \mathrm{ab}$ \\
\hline 1.68 (sunflowers) & $249.3 c$ & $208.2 \mathrm{a}$ & $28.7 \mathrm{a}$ \\
\hline 2.25 (sunflowers) & $229.3 \mathrm{bc}$ & $220.5 \mathrm{a}$ & $.15 .3 \mathrm{a}$ \\
\hline 3.36 (sunflowers) & $83.0 \mathrm{a}$ & $298.5 \mathrm{ab}$ & $48.6 \mathrm{ab}$ \\
\hline 3.36 (no sunflowers) & $-* *$ & $380.2 b$ & $131.5 b c$ \\
\hline 0.00 (no sunflowers) & $272.9 \mathrm{c}$ & $313.4 \mathrm{ab}$ & $172.4 \mathrm{c}$ \\
\hline
\end{tabular}

* Means within columns having the same letter are not significantly different at $P=0.10$ as analyzed by Duncan's Multiple Range Test.

** Treatment not included in 1982. 


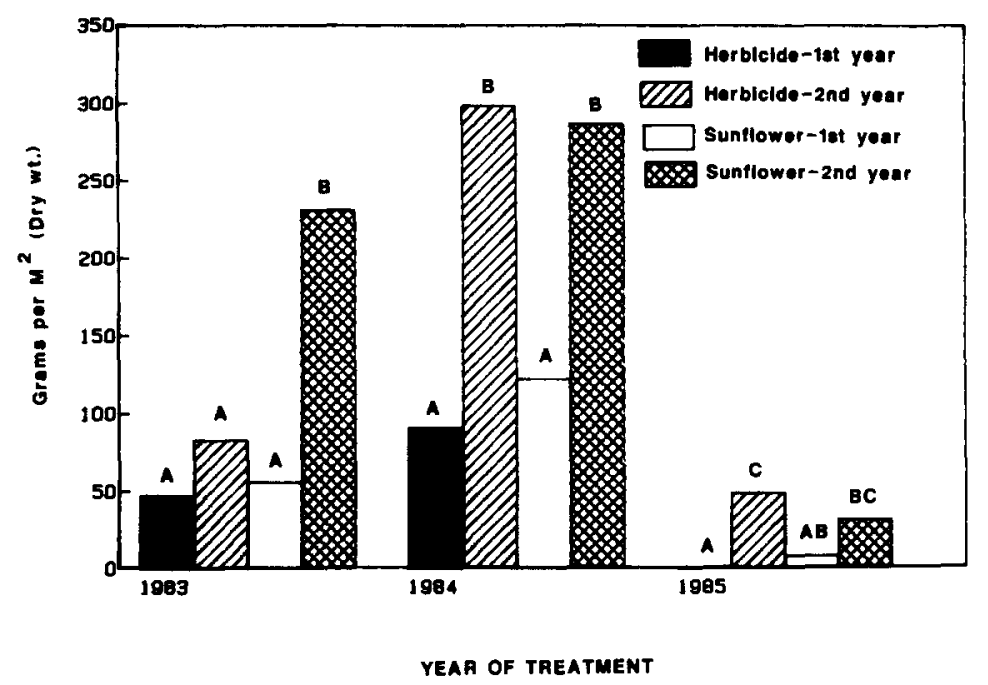

Fig. 1. Weed biomass [Grams per $\mathbf{M}^{2}$ (dry wt.)] in first- and second-year sunflower plots and sunflower plots treated with EPTC at $3.36 \mathrm{~kg} / \mathrm{ha}$. Bars within each year having the same letter are not different at $P=0.10$ as analyzed by Duncan's Multiple Range Test.

Second-year plots

Plots were tilled to a depth of $15 \mathrm{~cm}$ before treatment. The integrity of design was maintained from the first year and the same treatments were applied to each plot. Weed density, weed biomass, sunflower emergence and harvest data were obtained as described above. The data were analyzed using ANOVA and Duncan's Multiple Range Test.

\section{Results and discussion}

In the first-year plots, weed biomass did not differ among herbicide treatments or with sunflower only for all years (Table 1). Open plots had a greater biomass of weeds than other treatments including the openherbicide treated plots. Previous research ${ }^{13}$ demonstrated the allelopathic nature of these hybrid sunflowers on weeds, but it was not anticipated that weed control caused by sunflower would be equivalent to treatment with an herbicide (Table 1).

The biomass of weeds increased dramatically when plots were subjected to the same treatments one year later (Table 2). Only during 1985, when weed biomass was low in all plots (including first-year plots) did the sample variability allow statistical differences among treatments similar to that obtained on first-year plots. Fig. 1 illustrates the weed biomass in first- and second-year plots that received $3.36 \mathrm{~kg} / \mathrm{ha}$ EPTC plus sunflowers and sunflower plots without herbicide treatment. The biomass of weeds was greater in plots receiving the same treatment in the second year, and this trend was evident even when weed emergence differed between years e.g., 1984 vs 1985 . 


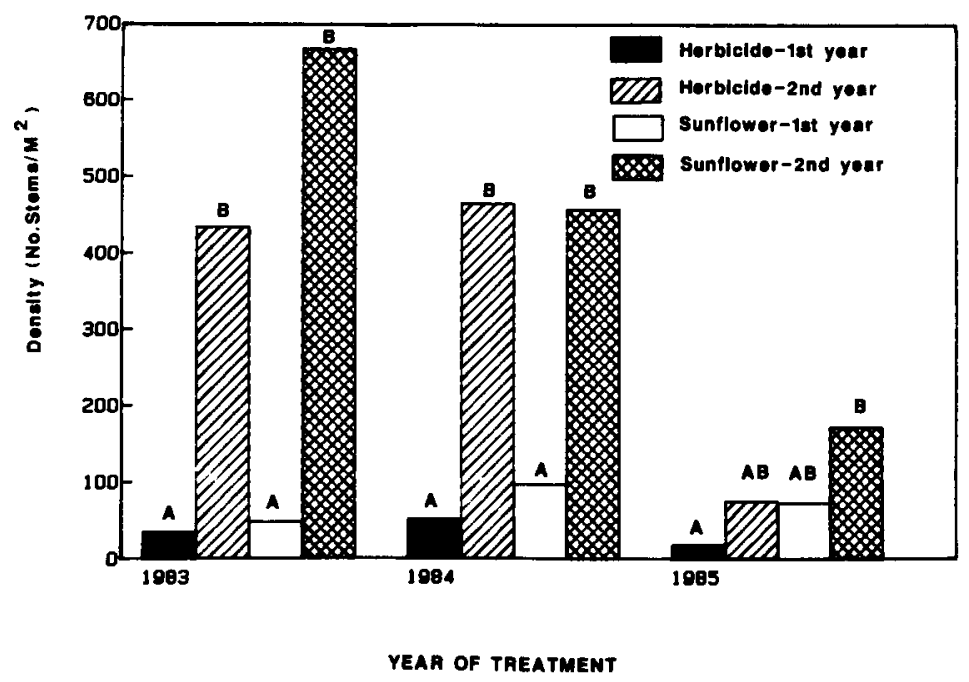

Fig. 2. Weed density (No. stems/ $/ \mathbf{M}^{2}$ ) in first- and second-year sunflower plots and sunflower plots treated with EPTC at $3.36 \mathrm{~kg} / \mathrm{ha}$. Bars within each year having the same letter are not different at $P=0.05$ as analyzed by Duncan's Multiple Range Test.

The pattern of weed density was the same among treatments as that of biomass but was more variable. High weed densitites in second-year plots during 1983 (Fig. 2) reflect drought conditions with high weed emergence but relatively lower biomass (Fig. 1) than occurred in 1984.

The weed population was dominated by redroot pigweed (Amaranthus retroflexus L.), common lambsquarters (Chenopodium album L.), Cana-

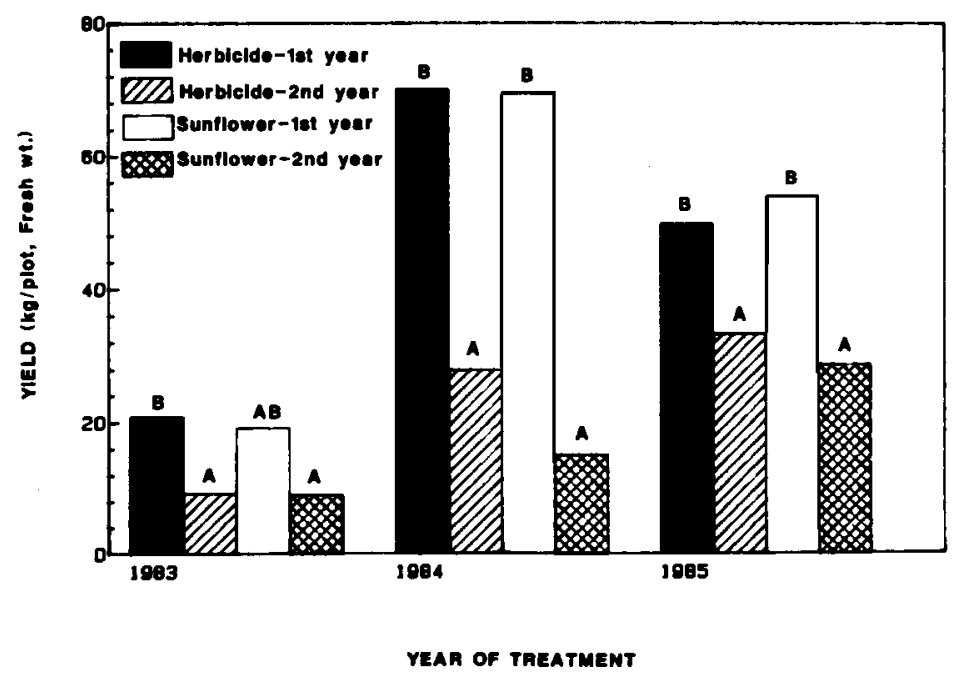

Fig. 3. Yield of sunflowers (kg/plot, fresh wt.) in first- and second-year sunflower plots and sunflower plots treated with EPTC at $3.36 \mathrm{~kg} / \mathrm{ha}$. Bars within each year having the same letter are not different at $P=0.05$ as analyzed by Duncan's Multiple Range Test. 


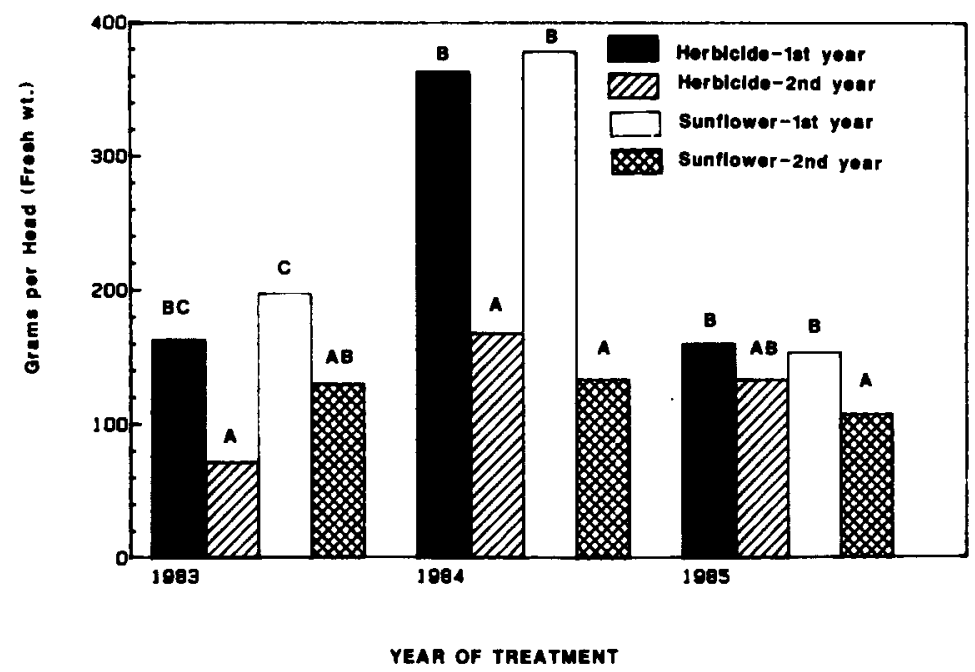

Fig. 4. Average fresh weight of harvested heads from first- and second-year sunflower plots and sunflower plots treated with EPTC at $3.36 \mathrm{~kg} / \mathrm{ha}$. Bars within each year having the same letter are not different at $P=0.05$ as analyzed by Duncan's Multiple Range Test.

da thistle [Cirsium arvense (L.) Scop.], and giant foxtail (Setaria faberi Herrm.). There was no change in weed dominance during the experimental period or among first- and second-year plots.

The question arises then, why did greater weed densities and weed biomass occur in second-year plots? As was reported previously ${ }^{13}$, weed densities probably increased as a result of the culture technique by which all residues were incorporated, thus increasing the number of germinable weed seeds. A second contribution which occurred in these experiments was a decrease in the number of sunflowers which emerged in secondyear plots. Sunflower emergence in second-year plots was 13.5, 45.2, and 27.6 percent less than in first-year plots for 1983, 1984, and 1985 respectively. Six weeks after seeding and at the time of weed data collection, sunflower plants were approximately $50 \mathrm{~cm}$ tall, and in first-year plots, the canopy closure was nearly complete. However, in second-year plots, the poor sunflower emergence resulted in large open areas and less interference with weed germination and growth.

Sunflower yield was significantly less in second-year plots (Fig. 3), reflecting the poor emergence and greater competitive pressure from the weeds. The sunflowers in second-year plots were observed to be less vigorous and the weight of heads was reduced compared to those in first-year plots (Fig. 4).

The results presented here indicate that sunflowers interfered with weed germination and growth as much as did herbicide treatment in first-year plots. The reasons for the reduced sunflower emergence in 
second-year plots remain unclear but could have resulted from autotoxicity from incorporated sunflower residues as reported by others ${ }^{6,8,20}$ for plants of this genus. Other crops have been reported to be inhibited by the allelopathic interference from sunflowers ${ }^{2,15,19}$, and autotoxicity has been observed in other crops such as rice ${ }^{4}$. If autotoxicity by sunflowers occurred in these tests, the nature of the effect remains obscure because previous research ${ }^{13}$ did not indicate inhibition of sunflower seed germination by dried sunflower leaf and stem tissue. Time-course experiments are planned to determine the stages of sunflower residue decomposition that produce the effects on sunflower emergence observed in this study.

Acknowledgements The author thanks Mr L E Forrence and Ms L L Hobbs for their assistance in conducting this research.

\section{References}

1 Altieri M A and Doll J D 1978 The potential of allelopathy as a tool for weed management in crop fields. PANS 24, 495-502.

2 Bhowmik P C and Doll J D 1982 Corn and soybean response to allelopathic effects of weed and crop residues. Agron. J. 74, 601-602.

3 Bhowmik P C and Doll J D 1984 Allelopathic effects of annual weed residues on growth and nutrient uptake of corn and soybeans. Agron. J. 76, 383-388.

4 Chou C-H and Lin H-J 1976 Autointoxication mechanism of Oryza sativa. I. Phytotoxic effects of decomposing rice residues in soil. J. Chem. Ecol. 2, 353-367.

5 Cochran V L, Elliott L F and Papendick R I 1977 The production of phytotoxins from surface crop residues. Soil Sci. Soc. Am. J. 41, 903-908.

6 Cooper W S and Stoesz A D 1931 The subterranean organs of Helianthus scaberrimus. Bull. Torrey Bot. Club 58, 67-72.

7 Curtis J T and Cottam G 1950 Antibiotic and autotoxic effects in prairie sunflower. Bull. Torrey Bot. Club 77, 187-191.

8 Einhellig F A 1985 Effects of allelopathic chemicals on crop productivity. pp 109-130 In Bioregulators for Pest Control. Ed. P Hedin. A C S Symposium Series 276. Am. Chem. Soc. Washington D C.

9 Goldsmith F B and Harrison C M 1976 Description and analysis of vegetation. In Methods in Plant Ecology Ed. SB Chapman pp 85-155. Halsted Press. John Wiley and Sons. New York.

10 Hall A B, Blum U and Fites R C 1982 Stress modification of allelopathy of Helianthus annuus L. debris on seed germination. Am. J. Bot. 69, 776-783.

11 Irons S M and Burnside O C 1982 Competitive and allelopathic effects of sunflower (Helianthus annuus). Weed Sci. 30, 372-377.

12 Koeppe D E, Southwick L M and Bittell J E 1976 The relationship of tissue chlorogenic acid concentrations and leaching of phenolics from sunflowers grown under varying phosphate nutrient conditions. Can. J. Bot. 54, 593-599.

13 Leather G R 1983 Sunflowers (Helianthus annuus) are allelopathic to weeds. Weed Sci. 31, $37-42$.

14 Leather G R 1983 Weed control using allelopathic crop plants. J. Chem. Ecol. 9, 983-989.

15 Menges R M and Tamez S 1981 Common sunflower (Helianthus annuus) interference in onions (Allium cepa). Weed Sci. 29, 641-647.

16 Nelson S H and Fedec P 1982 Inhibitory effects of confection sunflower hulls. HortScience 17, 887-888. 
17 Putnam A R and Duke W B 1978 Allelopathy in agroecosystems. Annu. Rev. Phytopathol. $16,431-451$.

18 Putnam A R, Defrank J and Barnes J P 1983 Exploitation of allelopathy for weed control in annual and perennial cropping systems. J. Chem. Ecol. 9, 1001-1010.

19 Schon M K and Einhellig F A 1982 Allelopathic effects of cultivated sunflower on grain sorghum. Bot. Gaz. 143, 505-510.

20 Wilson R E and Rice E L 1968 Allelopathy as expressed by Helianthus annuus and its role in old-field succession. Bull. Torrey Bot. Club 95, 432-448. 